\title{
Evaluation of antithrombotic and anti-ischemic effects of morinda citrifolia in renal autotransplantation in rats*
}

\author{
Murat KARABAĞLI' ${ }^{1}$, Kürşat ÖZER ${ }^{1}$, Alev AKDOĞAN KAYMAZ ${ }^{2}$, Aydın GÜREL ${ }^{3}$, \\ Özge ERDOĞAN ${ }^{3}$, Gamze KARABAĞLI ${ }^{4}$
}

University of Istanbul, Faculty of Veterinary Medicine, ${ }^{1}$ Department of Surgery, ${ }^{2}$ Department of Internal Medicine, ${ }^{3}$ Department of Pathology, Avc1lar; ${ }^{4}$ İstanbul Municipality, Cebeci Provisional Animal Shelter, Habipler mah, 2689. sok, No:17 Sultangazi, İstanbul, Turkey.

\begin{abstract}
Summary: Although it is not performed as common as in humans, kidney transplantation is an effective treatment option for end-stage renal failure in dogs and cats. Ischemia/reperfusion injury is an inevitable result of kidney transplantation and it may cause delayed graft function that leads to a reduction in the longevity of allograft. In this study we aimed to evaluate the effects of Morinda citrifolia derived fruit juice on post-autotransplant ischemia/reperfusion injury. Twenty four adult, male Spraque-Dawley rats weighing 300-350 g were used. The rats were randomly divided into three groups of eight each. Rats in the Control Group were orally administered with saline solution $(0.5 \mathrm{ml} /$ day $)$, for 7 days. Rats in M1 Group were orally administered with morinda citrifolia fruit juice (Alnoni, Hanojou-Europe Ltd, Dinxperlo, Holland), $0.5 \mathrm{ml} / \mathrm{day}$, for 7 days whereas rats in M2 Group were orally administered with the same morinda citrifolia fruit juice $(1 \mathrm{ml} /$ day $)$, for 7 days. In the $8^{\text {th }}$ day, rats were anesthetized and orthotopic unilateral renal autotransplantation was performed. Rats were euthanized after 24 hour reperfusion and ischemic kidneys were sent for histopathological examination. Formalin-fixed paraffin-embedded tissue sections were evaluated and scored according to the parameters of tubular brush border loss, mononuclear cell infiltration, degeneration, hyalin formation in tubul lumens, thrombosis and tubular necrosis. Mononuclear cell infiltration in M2 group was found to be significantly different $(\mathrm{P}<0.05)$ than those of Control and M1 groups. Thrombosis was not observed in any of the histopathological sections. As a result, a significant improving effect on the ischemia/reperfusion injury of Morinda citrifolia fruit juice was not determined in rats after renal autotransplantation.
\end{abstract}

Keywords: Autotransplantation, ischemia, kidney, morinda citrifolia, reperfusion.

\section{Renal ototransplantasyon yapılan sıçanlarda morinda citrifolia 'nın antitrombotik ve anti-iskemik etkilerinin değerlendirilmesi}

Özet: Böbrek transplantasyonu, son dönem böbrek yetmezliğinin tedavisi amacıyla, insanlardaki kadar yaygın olmamakla birlikte, kedi ve köpekler için de kullanılan bir renal replasman tedavisidir. İskemi/reperfüzyon hasarı ise böbrek nakillerinde kaçınılmaz olarak karşımıza çıkan ve gecikmiş gref fonksiyon bozukluğuna neden olarak nakledilen organın yaşam süresini kısaltan bir etken olarak varlığını sürdürmektedir. Bu çalışma ile tropikal bir meyveden elde edilen Morinda citrifolia meyve suyunun böbrek ototransplantasyonu sonrası oluşan iskemi/reperfüzyon hasarı üzerine etkilerini değerlendirmek amaçlanmıştır. Bu maksatla ağırlıkları 300-350 g arasında değişen, 24 adet Spraque-Dawley ırkı erkek sıçan, Kontrol, M1 ve M2 olmak üzere 3 gruba ayrıldı. Preoperatif olarak, Kontrol grubundaki sıçanlara \% $0,9 \mathrm{NaCl}$ solüsyonu (0,5 ml/gün), $\mathrm{M} 1$ grubuna Morinda citrifolia meyve suyu (0,5 ml/gün), M2 grubuna ise yine Morinda citrifolia meyve suyu ( $1 \mathrm{ml} /$ gün) oral yolla 7 gün boyunca uygulandı. Sıçanlar 8 . gün anesteziye alınarak, ortotopik unilateral böbrek ototransplantasyonu gerçekleştirildi. Sıçanlara, 24 saatlik reperfüzyon süresi sonunda ötanazi işlemi uygulandı ve iskemik böbrekler alınarak histopatolojik incelemeye gönderildi. Kesitler, histopatolojik muayene sonuçlarına göre, tubül firçamsı kenar kaybı, mononükleer hücre infiltrasyonu, dejenerasyon, tubul lumenleri içinde hyalin oluşumu, tromboz ve tubüler nekroz parametreleri açısından değerlendirilerek skorlandı. Mononükleer hücre infiltrasyonu açısından M2 grubu ile M1 ve Kontrol grubu arasındaki fark ise önemli bulundu $(\mathrm{P}<0,05)$. Histopatolojik kesitlerin hiçbirinde tromboz varlığına rastlanmadı. Sonuç olarak sıçanlarda, Morinda citrifolia meyve suyunun böbrek ototransplantasyonları sonrası oluşan, iskemi/reperfüzyon hasarı üzerine önemli bir iyileştirici etkisi olmadığı sonucuna varıldı.

Anahtar sözcükler: Böbrek, iskemi, morinda citrifolia, ototransplantasyon, reperfüzyon.

\footnotetext{
* This study is summarized from phd thesis.
} 


\section{Introduction}

Transplanted organs experience several episodes of ischemia/reperfusion injury (IRI) during procurement and transplantation and it may result in delayed graft function (DGF) (3). A meta-analysis of 34 studies from 1988 through 2007 concluded that patients with DGF had a $49 \%$ pooled incidence of acute rejection compared to $35 \%$ incidence in non-DGF patients (23). Poor kidney function in the first week of graft life is detrimental to the longevity of the allograft (17). Because of this reason, agents proposed to be useful in the clinical setting of renal IRI, continues to investigate (16).

First successful renal transplantation in cats was done in 1987 and since than it has become a treatment choice for cats with chronic renal failure (10). In time, change the vessels in recipient side to vascular anastomosis and nonpenetrating vascular staples like techniques were described to reduce warm ischemia and surgical time $(1,10)$. Although, warm ischemia time was successfully decreased by nonpenetrating vascular staples technique, difficulty to use in less than $1.5 \mathrm{~mm}$ renal artery diamater and high price like disadvantages have rectrict the widespread use in veterinary practice (10). Because we know that, warm ischemia time greater than 40 minutes is significantly increased the incidence of the acute tubular necrosis and allograft rejection, reducing the effects of IRI still an important issue in veterinary medicine (1).

Morinda citrifolia has been used in folk remedies by Polynesians for over 2000 years, and is reported to have a broad range of therapeutic effects including antioxidant, antispasmodic and vasodilatator, hypoglycemic, hepatoprotective and immunstimulant $(4,13,14,20)$. In toxicity tests of morinda citrifolia, histopathological changes in kidneys or elevation of serum creatinine concentrations were not determined even in high doses (21). Also, inhibitory potential on ethylene glycol induced nephrolithiasis and urolithiasis were determined in experimental studies $(2,19)$.

The aim of our study was to histopathologically evaluate the effect of morinda citrifolia fruit juice to protect the renal graft from IRI in unilateral renal autotranplantation model.

\section{Materials and Methods}

Animals and experimental design: Animal procedures were approved by University of Istanbul, Animal Experiments Local Ethic Committe (assize number: 2012/151). Twenty four adult, male SpraqueDawley rats weighing 300-350 g were used. All animals were fed with a standard diet of rat chow and water ad libitum and kept them in a temperature-controlled environment $\left(20^{\circ} \mathrm{C}\right.$ to $\left.22^{\circ} \mathrm{C}\right)$ with an alternating cycle of 12 hour light and dark.
Rats were divided into 3 groups. For rats in control group, $0.9 \% \mathrm{NaCl}$ solution $0.5 \mathrm{ml} / \mathrm{day}$; in $\mathrm{M} 1$ group, morinda citrifolia fruit juice (Alnoni, Hanojou-Europe Ltd, Dinxperlo, Hollanda) $0.5 \mathrm{ml} /$ day and in $\mathrm{M} 2$ group the same morinda citrifolia fruit juice $1 \mathrm{ml} /$ day were orally administred for 7 days. The dose of noni fruit juice was arbitrarily determined based on a previous conducted study (18). On the other side, frequency of drinking of noni is more important than the amount was determined (20). In the eight day, rats were anesthetized and orthotopic unilateral renal autotransplantation was performed. Rats were euthanized after 24 hour reperfusion and ischemic kidneys were sent to histopathologic examination. The reason of the waiting for 24 reperfusion is, peak renal injury occured 24 hour following ischemia and this time point is useful in monitoring the protective effects of new investigational agents (22).

Surgical procedures: Anesthesia was obtained by means of intramuscular injection of xylazine $\mathrm{HCl}$ (Rompun ${ }^{\circledR}$, Bayer, Turkey) and ketamine $\mathrm{HCl}$ (Ketalar ${ }^{\circledR}$, Pfizer, Turkey) and maintained with inhaled isoflurane (İsoflurane USP ${ }^{\circledR}$ Adeka, Turkey). Midline laparotomy was performed, the small bowel was exteriorized and wrapped in warm saline-soaked gauze. The left kidney, inferior vena cava and aorta abdominalis were exposed. The left renal artery and vein were mobilized after ligating and dividing the adrenal branches. Inferior vena cava at the caudal of renal vein and aorta abdominalis at the cranial of renal artery were occluded with a clamp. A 26 gauge needle was inserted into aorta abdominalis in caudal abdomen and kidney were flushed with heparinized (1000 IU heparine sodium in $1000 \mathrm{ml}$ solution) $0.9 \% \mathrm{NaCl}$. Before unclamping, two double clamp approximator were applied on left renal artery and vein (Figure 1a) and two clamps on inferior vena cava and aorta abdominalis were removed. The renal artery and vein were sectioned between the tips of the each approximator and the adventitia was cleared from the vessel ends to prevent thrombosis. For suturing the renal artery, 10/0 nylon (Ethilon ${ }^{\circledR}$, Jhonson \& Jhonson, Belgium) suture material was used with simple interrupted pattern and for renal vein anastomosis 9/0 nylon (Ethilon ${ }^{\circledR}$, Ethicon, United Kingdom) suture material was preferred with simple continious pattern (Figure $1 \mathrm{~b}, \mathrm{c})$. The mean warm ischemia time was $62( \pm$ 4) minutes. After the ureter was sectioned, a small stab wound incision is made in the fundus of the bladder wall, and then a small forceps clamp is inserted through the posterior wall. The tip of the ureter is grasped and pulled into the bladder. One suture is placed at the junction of the ureter with the bladder, to secure the ureter to the serosa. 


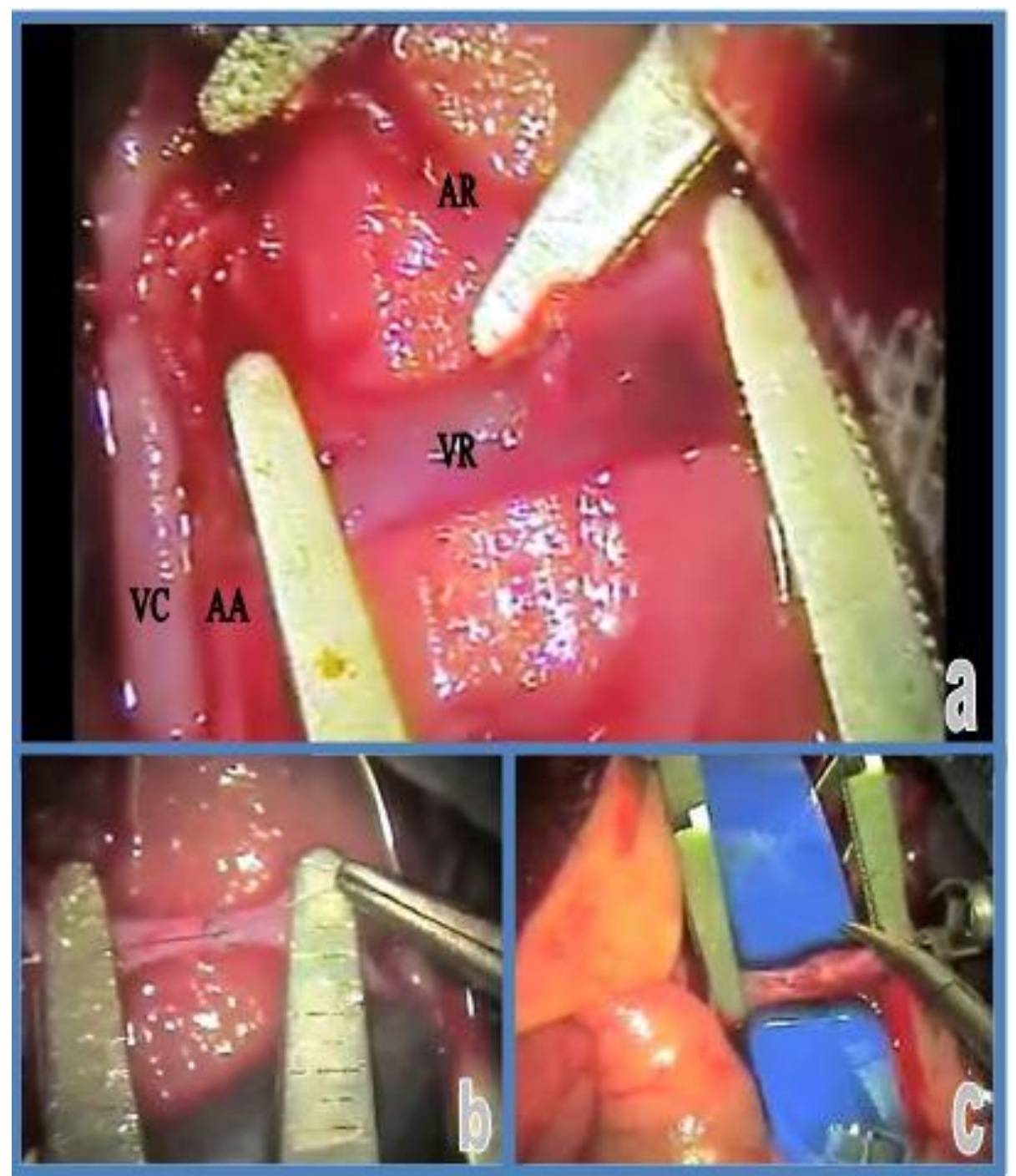

Figure 1. a, Double clamp approximators were applied on left renal artery and vein, VR: vena renalis, AR: arteria renalis, CV: inferior vena cava, AA: aorta abdominalis; b, Renal artery anastomosis; c, Renal vein anastomosis.

Şekil 1. a, Renal arter (RA) ve vena (RV) üzerine damar yaklaştırma klemplerinin yerleştirilmesi, VR: renal vena, AR: renal arter, $\mathrm{CV}$ : inferior vena cava, AA: aorta abdominalis; b, renal arter anastomozu; c, renal vena anastomozu.

Pathomorphologic examination: At necropsy, the left kidneys were removed and fixed in $10 \%$ formalin, for histopathologic examiation as described previously (12), stained with hematoxylin-eosin and evaluated under light microscope. Sections were evaluated and scored, according to hispathologic examination results for tubular brush border loss, parenchyma and vacuolar degeneration in cortical tubul epithelium, hyaline bodies in tubul lumens, infiltration of mononuclear cells, thrombosis and tubular necrosis parameters. Severity of those 6 parameters present on each slide were converted into a numeric score as follows: 0 (absent), 1 (mild), 2 (moderate), 3 (severe). Intensity and prevalence of these 6 microscopic criteria were numerically evaluated by examination of 10 different microscopic field in $20 \times$ magnification and than the sum of these numerical scores were diveded to 10 .
Statistical analysis: To compare the 3 groups for tubular brush border loss, parenchyma and vacuolar degeneration in cortical tubul epithelium, hyaline bodies in tubul lumens, infiltration of mononuclear cells, thrombosis and tubular necrosis scores, Kruskal-Wallis test and to analyze differences between groups, MannWhitney U test were used.

\section{Results}

Although, when looked at the mean scores of the histopathologic parameters of three groups, anyone can be simply realized that, morinda citrifolia fruit juice has reducing effects on tubular brush border loss, degeneration, hyalin bodies formation in tubul lumens and tubular necrosis parameters in IRI of kidney (Table 1) but in statistical analysis of those parameters, any significant differences between groups were not determined. The 
Table 1. Statistical analysis results of histopathologic parameters.

Tablo 1. Histopatolojik parametrelerin istatistiksel analiz sonuçları.

\begin{tabular}{|c|c|c|c|c|c|c|c|c|}
\hline \multirow{2}{*}{ Parameters } & \multicolumn{2}{|c|}{ Control Group } & \multicolumn{2}{|c|}{ M1 Group } & \multicolumn{2}{|c|}{ M2 Group } & \multicolumn{2}{|c|}{ Significance } \\
\hline & Mean & Std. Error & Mean & Std. Error & Mean & Std. Error & Chi-square & P-value \\
\hline Tubular Brush Border Loss & 2,50 & 0,19 & 1,63 & 0,42 & 1,63 & 0,27 & 4,815 & 0,09 \\
\hline Degeneration & 2,38 & 0,18 & 1,88 & 0,23 & 1,75 & 0,31 & 3,354 & 0,19 \\
\hline Tubular Necrosis & 2,38 & 0,27 & 2,13 & 0,4 & 2,0 & 0,5 & 0,078 & 0,97 \\
\hline Hyalin Bodies in Tubul Lumens & 1,50 & 0,19 & 1,88 & 0,4 & 1,65 & 0,5 & 0,922 & 0,63 \\
\hline Mononuclear Cells Infiltration & $0,50^{\mathrm{b}}$ & 0,19 & $1,0^{\mathrm{b}}$ & 0,19 & $1,25^{\mathrm{a}}$ & 0,16 & 6,968 & 0,03 \\
\hline
\end{tabular}

$\mathrm{a}, \mathrm{b}$ : The differences between mean values, which expressed in the same row with different letters are important. a, b: Aynı satırda farklı harfler kullanılarak belirtilmiş ortalama değerler arasındaki farklılıklar önemlidir.

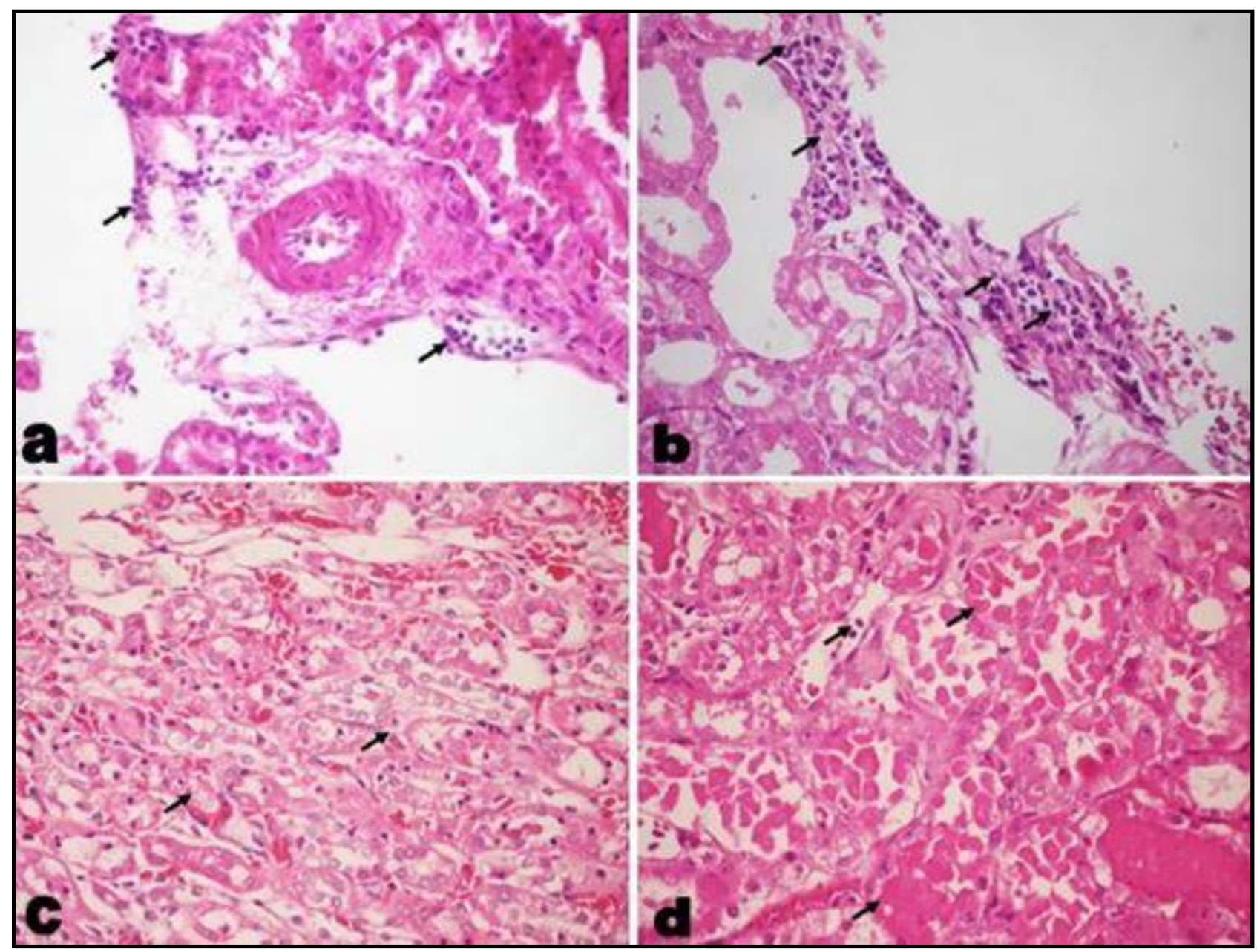

Figure 2. Black arrows in photomicrographs showing kidney tissues of control and M2 groups. a, Mild $(+1)$ mononuclear cells infiltration in Control group (40×) (H.E.); b, Moderate (+2) mononuclear cells infiltration in M2 group (40×) (H.E.); c, mild (+1) tubular necrosis in M2 group (20×) (H.E.); d, and severe (+3) tubular necrosis in Control group (40×) (H.E.).

Şekil 2. Fotomikrograflardaki siyah oklar, Kontrol ve M2 grupların böbrek dokularını göstermektedir. a, Kontrol grubunda hafif $(+1)$ mononükleer hücre infiltrasyonu $(40 \times)$ (H.E.); b, M2 grubunda orta derece $(+2)$ mononükleer hücre infiltrasyonu (40×) (H.E.); c, M2 grubunda hafif (+1) tubuler nekroz (20×) (H.E.); d, Kontrol grubunda şiddetli (+3) tubuler nekroz (40×) (H.E.). 
presence of thrombosis was not observed in any of the histopathologic sections. Infiltration of mononuclear cells in lenfoid character in M2 group were found to be significantly different $(\mathrm{P}<0.05)$ than those of Control and $\mathrm{M} 1$ groups and it was the one statiscally significant result in our study (Table 1). The histopathologic sections about tubular necrosis and infiltration of mononuclear cells in lenfoid character can be seen in Figure 2.

\section{Discussion and Conclusion}

Agents proposed to be useful in the clinical setting of renal IRI, continues to investigate. Fruit juice of Morinda citrifolia is a well-known health drink and has various pharmacological properties including antioxidant and anti-inflammatory effects $(5,6,8,11,15)$. On the other side, very few studies have been made on antiischemic effect of Morinda citrifolia and those studies related to the effects on brain damage associated with IRI $(7,9)$. Researchers were figured out the IRI preventive mechanism of morinda citrifolia in one of those papers and in conclusion they found that morinda citrifolia could facilitate insulin secretion after ischemic stress and attenuate the development of glucose intolerance, which may lead to its protective effect against ischemic stres (8).

On the other hand, modulatory effect of Morinda citrifolia against ethylene glycol induced nephrolithiasis and treatment results of ethylene glycol and ammonium chloride induced kidney disease were carried out $(2,19)$ but histopathologic data obtained in these two studies were not detaily evaluated.

Also, inflammatory cell infiltration is not a normal histopathologic finding in renal ischemia-reperfusion injury (22) and observation of intense infiltration of mononuclear cells in lenfoid character in M2 study group can be explain with dose dependent result of Morinda citrifolia.

Above all, organ transplantation is a different issue and almost all of the transplant recipients (except identical twins) have to use some immunosuppressive drugs in lifelong manner. As we mentioned before, morinda citrofolia have some important features like antioxidant and hypoglycemic effects but other side morinda has some immunstimulant effect which we don't want in pre and post-transplantation period.

In conclusion we found that, morinda citrifolia fruit juice did not have statisticaly important IRI reducing effect in rat kidney after unilateral autotransplantation and infiltration of mononuclear cells in lenfoid character in M2 group was leaves as a question mark for allotransplantations which may lead to harmful effects in immunsuppressed allograft recipients.

\section{References}

1. Bernsteen L, Gregory CR, Pollard RE, Griffey SM, Menwrath V (1999): Comparison of two surgical techniques for renal transplantation in cats. Vet Surg, 28, 417-420.

2. Bhavani R, Nandhini S, Rojalakshmi B, Shobana R, Rajeshkumar S (2014): Effect of noni (Morinda citrifolia) extract on the treatment of ethylene glycol and ammonium chloride induced kidney disease. IJPSR, 5, 249-256.

3. Dicken DH, Fuggle K, Fuggle S (2000): Impact of ischemia/reperfusion injury and early inflammatory responses in kidney transplantation. Transplant Rev, 14, 210-224.

4. Gilani AH, Mandukhail SR, Iqbal J, et al. (2009): Antispasmodic and vasodilatator activities of Morinda citrifolia root extract are mediated through blockade of voltage dependent calcium chanels. BMC Complemantary and Altern Med, 10, 1-9.

5. Giullian JA, Helderman JH (2008): Do calcium channel blockers prevent delayed graft function after renal transplantation? Nat Clin Pract Nephrol, 4, 192-193.

6. Guan X, Dei-Anane G, Bruns H, et al. (2009): Danshen protects kidney grafts from ischemia/reperfusion injury after experimental transplantation. Transpl Int, 22, 232241.

7. Harada S, Hamabe W, Kamiya K, et al. (2009): Preventive effect of morinda citrifolia fruit juice on neuronal damage induced by focal ischemia. Biol Pharm Bull, 32, 405-409.

8. Harada S, Hamabe WF, Kamiya K, et al. (2010): Morinda citrifolia fruit juice prevents ischemic neuronal damage through suppression of the development of postischemic glucose intolerance. J Nat Med, 64, 468-473.

9. Jang HR, Gandolfo MT, Ko GJ, et al. (2009): The effect of murine anti-thymocyte globulin on experimental kidney warm ischemia-reperfusion injury in mice. Transpl Immunol, 22, 44-54.

10. Iwai S, Endo K, Hakamata Y, Gregory CR, Kobayashi E (2006): Use of nonpenetrating vascular closure staples in feline renal transplantation. Microsurgery, 26, 13-16.

11. Li Z, Nickkholgh A, Yi X, et al. (2009): Melatonin protects kidney grafts from ischemia/reperfusion injury through inhibition of $N F-k B$ and apoptosis after experimental kidney transplantation. J Pineal Res, 46, 365372.

12. Luna L.G. (1968): Manual of histologic staining methods of the armed forces institute of pathology $\left(3^{\text {rd }} \mathrm{Ed}\right)$. Blakiston Division, McGraw-Hill Book Company, Newyork.

13. Nayak S, Mengi S (2010): Immunostimulant activity of noni (morinda citrifolia) on $T$ and B lymphocytes. Pharm Biol, 2010, 48, 724-731.

14. Nayak BS, Marshall JR, Isitor G, et al. (2011): Hypoglycemic and hepatoprotective activity of morinda citrifolia (noni) in diabetic rats. Evid Based Complement Alternat Med, 2011, 1-5.

15. Neri F, Puviani L, Tsivian M, et al. (2007): Protective effect of inhibitor of interleukine-8 (Meraxin) from ischemia and reperfusion injury in a rat model of kidney transplantation. Transplant Proc, 39, 1771-1772. 
16. Sener G, Sehirli AO, Keyer-Uysal M, et al. (2002): The protective effect of melatonin on renal ischemiareperfusion injury in the rat. J Pineal Res, 32, 120-126.

17. Siedlecki A, Irish W, Brennan DC (2011): Delayed graft function in kidney transplant. Am J Transplant, 11, 22792296.

18. Taskin EI, Akgün-Dar K, Kapucu A, et al. (2009): Apoptosis-inducing effects of morinda citrifolia $l$. and doxorubucin on the Ehrlich ascites tumor in Balb-c mice. Cell Biochem Funct, 27, 542-546.

19. Verma NK, Patel SS, Saleem TSM, Christina AJM, Chidambaranathan N (2009): Modulatory effect of noniherbal formulation against ethylene glycol-induced nephrolithiasis in albino rats. J Pharm Sci, 1, 83-89

20. Wang MY, West BJ, Jensen CJ, et al. (2002): Morinda citrifolia (Noni): A literature review and recent advances in Noni research. Acta Pharmacol Sin, 23, 1127-1141.
21. West BJ, Su CX, Jarakae Jensen J (2009): Hepatotoxicity and subchronic toxicity tests of Morinda citrifolia (noni) fruit. J Toxicol Sci, 34, 581-585.

22. Williams P, Lopez H, Britt D, et al. (1997): Characterization of renal ischemia-reperfusion injury in rats. JPM, 37, 1-7.

23. Yarlagadda SG, Coca SG, Formica RN, et al. (2009): Association between delayed graft function and allograft and patient survival: A systematic review and metaanalysis. Nephrol Dial Transplant, 24, 1039-1047.

Geliş tarihi: 08.09.2014 / Kabul tarihi: 11.02.2015

\author{
Address for correspondence: \\ Dr. Murat Karabağll, \\ University of Istanbul, \\ Faculty of Veterinary Medicine, \\ Department of Surgery, Avcilar, Istanbul, Turkey. \\ e-mail:muratkarabagli@yahoo.com
}

